\title{
The Significance of the Presence of Pollen in the Food of Worker Larvae of the Honey-bee
}

\author{
By J. SIMPSON \\ (Bee Research Department, Rothamsted Experimental Station, Harpenden, Herts.)
}

Summary

I. From a study of the quantity of undigested shells of pollen grains in the gut of worker honey-bee larvae it is concluded that the larvae receive a variable quantity of pollen in their food in summer and sometimes none at all in winter.

2. Probably less than one-tenth of the nitrogen requirements of growing larvae are obtained from the pollen in their food.

\section{INTRODUCTION}

$\mathrm{W}$

ORKER larvae of the honey-bee are fed on a fluid which is, at least in part, a secretion of the pharyngeal glands of the adult worker bees (Schiemenz, I 883; Langer, I912). Köhler (1922) and others have found many pollen grains in the food of larvae over 3 days old, but few in the food of younger larvae. Since it was not known what contribution this pollen makes to larval nutrition, estimates have been made of the quantity of pollen swallowed and the amount of nitrogen which it can provide.

\section{Pollen grains in the larval gut}

\section{METHODS}

The gut contents of fully grown worker larvae were stained and suspended in I c.c. of glycerine and an estimate by haemacytometer counts was made of the number of shells of pollen grains in each gut. These estimates represented the total amount of pollen swallowed by the larvae, since the mid-gut and Malpighian tubules have no connexion with the hind-gut in the larval stage of the honey-bee (Snodgrass, 1925) and the shells of the pollen grains are not digested (Parker, 1926; Whitcomb and Wilson, 1929). The estimate of the mean number of pollen grains per larva for each group is given in table $x$.

Comparison of the variation between to counts on separate larvae with that between ro counts on one larva shows that there were differences in the number of pollen grains in individual larvae $(P<0.001)$. The larvae examined on 23 February 1953 contained nearly as many pollen grains as those examined in summer, but there were fewer grains in the larvae examined on Io February. No pollen was found in the larvae from the first comb of colony $A$ (although the gut of one larva was stained and crushed under a coverslip and examined as a whole); this comb contained no stored pollen. The other larvae came from combs in which pollen in good condition was stored within the area covered by bees; all the pollen grains identified in winter larvae were from summer flowering plants and could not have been recently collected.

[Quarterly Journal of Microscopical Science, Vol. 96, part 1: pp. 117-120, March 1955.] 
Pollen available in the field

Samples of trapped pollen, each of approximately 5 g. (i.e. about $\mathrm{I}, 000$ pellets of pollen) from a $I$ to 3 days' catch were moistened, thoroughly mixed, and dried in an incubator at $33^{\circ} \mathrm{C}$. From each sample duplicate portions

TABLE I

Estimated number of pollen grains in the gut of fully grown worker larvae

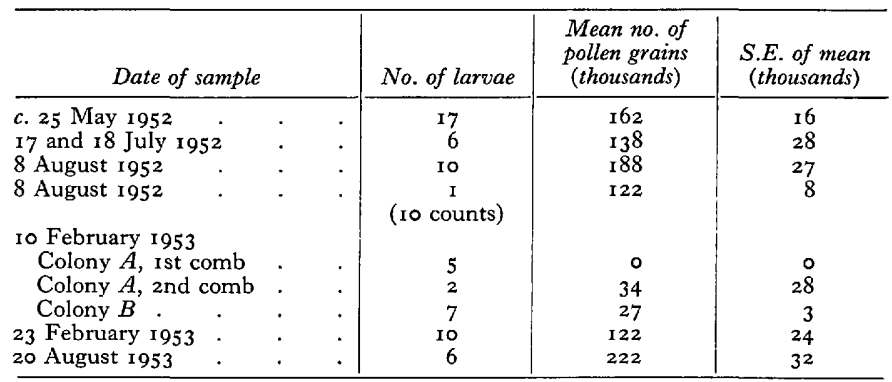

(about $30 \mathrm{mg}$.) were taken for nitrogen determinations by the micro-Kjeldahl method and about $100 \mathrm{mg}$. of the remainder was stained and suspended in 25 c.c. of glycerine. Ten fields of the haemacytometer were counted for each sample. The analysis of these samples (table 2) shows a mean nitrogen content

TABLE 2

Number of grains per mg. and per cent. nitrogen in samples of trapped pollen

\begin{tabular}{|c|c|c|}
\hline Date of sample & $\begin{array}{l}\text { Pollen grains } \\
\text { per mg. pollen } \\
\text { (thousands) }\end{array}$ & Per cent. $\mathrm{N}$ \\
\hline $\begin{array}{l}9 \text { June } 1951 \\
\text { 30 June I952 } \\
6 \text { July } 195^{2} \\
\text { 24 July } 1952 \\
\text { 13 August 1952* } \\
\text { 29-31 August 1952† }\end{array}$ & $\begin{array}{r}92 \\
126 \\
108 \\
65 \\
22 \\
29\end{array}$ & $\begin{array}{l}4.35 \\
3.52 \\
3.76 \\
2.57 \\
3.52 \\
3.86\end{array}$ \\
\hline MEAN & 74 & 3.59 \\
\hline
\end{tabular}

* 99 per cent. red clover pollen. +88 per cent. red clover pollen.

of 3.59 per cent. of the dry weight, which is close to that found by Todd and Bretherick (1942). It was observed that 99 per cent. (count of I,000 grains) of the pollen in the sample of 13 August $195^{2}$ came from red clover (Trifolium pratense).

The nitrogen content of the pollen swallowed by larvae

(a) Summer. Combination of the data in tables $I$ and 2 gives a mean of 
$0.078 \mathrm{mg}$. pollen nitrogen per larva for the summer larvae of $195^{2}$ but this estimate is probably very inaccurate because of the variation in size of the pollen grains of different plant species. The error can be considerably reduced for the larvae examined in August 1953 which contained only pollen from red clover, white clover, and sainfoin. For each of these larvae the proportion of pollen of each species was estimated (count of 1,000 grains) and after correction for grain size the amount of nitrogen represented by the pollen was calculated from the analysis of the nearly pure sample of red clover pollen obtained on 13 August 1952. This method gave a mean value of O.19 mg. N per larva ( 5 per cent. fiducial limits 0.14 to $0.23 \mathrm{mg}$.).

(b) Winter. The larvae from colony $B$ on Io February 1953 contained only red clover pollen and gave a mean of $0.042 \mathrm{mg}$. N per larva (5 per cent. fiducial limits 0.032 to $0.053 \mathrm{mg}$.).

\section{Discussion}

It has been estimated that $145 \mathrm{mg}$. (Alfonsus, 1933) or $125 \mathrm{mg}$. (Rosov, I944) of pollen are required to rear one worker larva; Haydak (1943) calculated that $3 \frac{1}{2} \mathrm{mg}$. of nitrogen were required. Melampy and others (1940) found that the bodies of mature worker larvae contained about $2 \mathrm{mg}$. of nitrogen but this quantity probably does not include the whole of the nitrogen in the pollen which the nurse bees used in producing pharyngeal gland secretion.

The contents of the pollen grains found in larvae in the present observations had been digested and so had presumably contributed to the nutrition of the larvae, but this pollen had probably not supplied more than a tenth of the nitrogen requirement of the summer larvae, while some of the winter larvae received much less pollen or none at all. The quantity of nitrogen supplied by pollen is insufficient even to supply the amount needed after the first 3 days of larval life (during which little pollen is present in the larval food), since Melampy and others ( $194^{\circ}$ ) found that larvae 3 days old contained only about $0.25 \mathrm{mg}$. of nitrogen. Haydak (1937) found that colonies without access to pollen continued to rear larvae for some time, the larval food being derived from reserves in the bodies of the adult bees. The young bees produced in Haydak's experiment might have been deficient in some respect, but no deficiency is likely to be associated with normal winter brood rearing, which occurs at a time when the adult bees have a considerable accumulation of protein in their fat bodies (Lotmar, 1939; Maurizio, 1950). Pollen is therefore not an essential constituent of the food of worker larvae, and the scarcity of pollen usually observed in the food of queen larvae cannot account for their differentiation from worker larvae.

Feeding on pharyngeal gland secretion makes possible the very rapid growth of young larvae and simplifies digestion and faecal disposal; hence it is difficult to understand why the larvae should receive any pollen directly. Haydak's (1943) suggestion that the presence of pollen in larval food is due to contamination of the mouth-parts of the nurse bees while eating pollen seems inadequate to explain the quantity found in larvae. Since, however, the 
120 Simpson-Pollen in the Food of Worker Larvae of the Honey-bee

sugar content of the food given to larvae of different ages appears to vary (v. Planta, 1888, 1889; Haydak, 1943) a more probable explanation is that the food receives an addition of sugary material from the bee's honey stomach which, in a nurse bee, will frequently contain some pollen in the process of being transferred to the ventriculus by the mechanism demonstrated by Bailey (1952).

I am indebted to Dr. N. Walker of the Soil Microbiology Department, Rothamsted Experimental Station, for the nitrogen analyses of pollen given in this paper.

\section{REFERENCES}

Alfonsus, A., r933. Arch. Bienenk., r4, 220.

BAILEY, L., 1952. J. exp. Biol., 29, 310.

HAYDAK, M. H., I937. J. econ. Ent., 30, 637.

- 1943. Ibid., 36, 778 .

KöHLER, A., I922. Verh. dtsch. zool. Ges., 27, 445.

LANGER, J., 1912. Quoted by Zander (1921).

Lotmar, R., 1939. Z. vergl. Physiol., 19, 673.

Maurizio, A., I950. Bee World, 31, 9.

Melampy, R. M., Willis, E. R., and McGregor, S. E., 1940. Physiol. Zool., r3, 283.

Parker, R. L., I926. Mem. Cornell agric. Exp. Sta., 98, I.

Planta, A. v., 1888, 1889. Hoppe-Seyl. Z., 12, 324; r3, 552.

Rosov, S. A., 1944. Bee World, 25, 94.

Schiemenz, P., 1883. Z. wiss. Zool., 38, 7r.

SNodgrass, R. E., 1925. Anatomy and physiology of the honeybee. New York (McGrawHill).

TOdD, F. E., and Bretherick, O., r942. J. econ. Ent., 35, 312.

Whitçoms, W., and Wilson, H. F., 1929. Bull. Wis. agric. Exp. Sta., 92.

ZANDER, E., I92 I. Das heben der Biene, and edit., Stuttgart (Ulmer). 